\title{
Evaluation of the Public Housing Projects Role in Contributing to Mitigation of Housing Crisis in Gaza Strip
}

\author{
Nabil El-Sawalhi", Mohammed Lafi \\ Civil Engineering Department, Faculty of Engineering, The Islamic University of Gaza, Gaza, Palestine \\ Email address: \\ nsawalhi@iugaza.edu.ps (N. El-Sawalhi),lafy_mohamed@hotmail.com (M. Lafi) \\ ${ }^{*}$ Corresponding author
}

To cite this article:

Nabil El-Sawalhi, Mohammed Lafi. Evaluation of the Public Housing Projects Role in Contributing to Mitigation of Housing Crisis in Gaza Strip. American Journal of Civil Engineering. Vol. 7, No. 4, 2019, pp. 88-100. doi: 10.11648/j.ajce.20190704.12

Received: June 24, 2019; Accepted: July 13, 2019; Published: August 15, 2019

\begin{abstract}
Gaza Strip faces large and accumulating shortfall between the built and needed houses due to a high natural population growth, very high population density, difficult political and economic conditions and a suffocating siege imposed, with a high unemployment rate. This has caused an increase in the ongoing gap between housing demands and supply. The most prominent public housing projects in Gaza Strip implemented during the time period from 1994 to 2017 have been introduced. The aim of this research is to improve the contribution of the public housing projects in alleviating of housing crisis in Gaza Strip. Literature review and questionnaire survey were used. 80 copies of the questionnaire were distributed randomly to experts working in the housing field in Gaza Strip. 73 copies of the questionnaire were received with response rate of $91.25 \%$. The most important result is that the public housing projects and public housing policies have a low rate in contribution to alleviating the housing crisis in Gaza Strip. There is lack of comprehensive, realistic and appropriate public housing policies. In addition to not reviewing and updating the public housing standards which have led to mistakes in the way of choosing the target group of public housing projects. The main obstacles facing the government in solving the housing crisis are lack of housing policies, shortage of economic resources of the government and citizens, shortage of the construction materials, high population density and high population growth rate.
\end{abstract}

Keywords: Public Housing, Housing Projects, Housing Standards, Housing Crisis, MPWH, Gaza Strip

\section{Introduction}

Gaza Strip faces a large and accumulating shortfall between the needed houses and the built. According to the United Nations Country Team in the occupied Palestinian territory (2017), the housing shortage in Gaza continues to be an issue of concern as housing shortage has increased from 71,000 housing units in 2012 to 120,000 in 2017- in large part due to natural population growth [1].

Gaza Strip with a population of $1,899,291$ individuals is considered as a densely populated area, which has area does not exceed 365 square kilometers and a very high population density reached to 5203 persons $/ \mathrm{km}^{2}$ in mid of 2017. It is actually very high population density compared to 509 persons $/ \mathrm{km}^{2}$ in West Bank [2]. Additionally, Gaza Strip has a high rate of annual population growth reached to $3.20 \%$ in 2017 [2]. Also, people live in difficult political and economic conditions and the government suffers from a suffocating siege imposed on Gaza Strip and its inhabitants, with a high unemployment rate. This has caused a rise in the proportion of people living in the same dwelling, the average density of the population in Gaza Strip was $1.7 \%$ per room, while $13.2 \%$ of the population lives 3 persons or more in the same room [3], and has caused an increase in the ongoing gap between housing demand and supply.

The need for housing is one of the constant and permanent needs. It cannot be said that there is an absolute end to this need, because it is renewed by population growth and the need to renovate dilapidated dwellings. There are few previous studies done on the evaluation of public housing projects in Gaza Strip. Most researches related to housing crisis deals with the issue of urban planning, or focus on a specific project only. Also, there is inconsistency and exaggeration observed in estimates of the size of the current housing gap in Gaza Strip and the absence of clear public housing policies. The aim of this paper is to improve the 
contribution of the public housing projects in alleviation of housing crisis in Gaza Strip. The specific objectives are: To estimate the housing gap by identifying the size of supply and demands. To evaluate the role of public housing projects in alleviating the housing crisis in Gaza Strip and to set out the main barriers that the government faced in alleviating the housing crisis.

Policy making and the drawing of future plans in the field of housing in the Palestinian Territory is contingent on the availability of estimates of future trends of housing statistics. This planning helps estimating the Palestinian future needs of housing units for a specific period of time; these estimations are based on the international experience and on the population projections by the PCBS [4].

According to the latest statistical data on the population and housing in Gaza Strip conducted by the PCBS in end of 2017, the number of housing units in Gaza Strip is approximately 403,259 [4], of which about $15 \%$ are empty or abandoned units, while the number of full families without the extended family account in Gaza Strip are 334,632 families [4]. But $62 \%$ of these families have extended families living in the same housing unit. Therefore, the total number of households, including the number of extended families is 542,103 families. Thus, there are about 138,844 family's need independent and decent housing. Estimates of the Ministry of Public Works and Housing (MPWH) showed that there are about 23,000 units of existing units are not fit for habitation and need to be demolished and rebuild again until the of 2017 [5]. Also, there are about 50 thousand housing units in Gaza Strip of existing units need to be renovated or repaired until the of 2017 [5].

The importance of this paper is that about $70 \%$ of the dwellings that need to be built, repaired, demolished and reconstructed cannot be built by the citizens themselves; they need assistance [5]. They live in difficult political and economic conditions and suffer from a suffocating siege imposed on Gaza Strip and its inhabitants, with unemployment rate has reached to $48 \%$ [4]. This large deficit in the estimated housing units needed in Gaza Strip until 2017 represents a serious housing gap and a real crisis. All the bodies working in the field of housing in Gaza Strip should join forces to deal with this crisis. If the gap left without any solutions, that will cause a humanitarian disaster in the next few years [6].

Abu Hantash mentioned in 2009 that the housing sector has a special nature because it is linked to many sectors of the state [7]. All (governmental, semi-governmental, international and private) organizations that shared in this sector are influencing and contributing in guiding it. However, no one can be alone in this sector because of the size, complexity and problems of this sector.

\section{Key Players in the Field of Housing}

MPWH is one of the most important bodies in the field of housing in Palestine as a whole in order to achieve sustainable urban development in the housing and infrastructure sector in Palestine. The Ministry's work is governed by a set of laws and regulations in force that regulate, direct and control the Ministry's activities, plans and policies [8]. It represents the official governmental body responsible for the public housing sector. It is responsible for providing affordable housing to all segments of the society and thus provides it through the establishment of communities and housing projects and offering them to different segments of society in different ways. They may receive free housing units while others to be paid for, in accordance with the Government's policies in the field of housing in accordance with the economic and social conditions [9].

This study will focus on evaluation of public projects implemented by the MPWH, in order to improve the role of these projects in alleviating the housing crisis in Gaza Strip.

MPWH has carried out a number of important housing projects from the beginning of its inception and diversified projects between housing projects and rehabilitation projects slums. Around 31 housing projects were carried out by the Ministry, or are still under implementation [5].

Palestinian Housing Council (PHC) is considered as a semi-governmental organization which was established in 1991 as a non-profit organization to provide housing. It is based in Jerusalem and has offices in most of the main cities in the West Bank and Gaza Strip. The Council is responsible for several new housing projects funded by the European Union and the US and Japanese governments [10]. Essawi mentioned in 2008 that the PHC has contributed to the development of the construction sector for multi-storey buildings [11]. The Council has built 1,198 housing units in Gaza Strip, benefiting 8386 Palestinian citizens. These units have been distributed to low-income groups to recover the cost of housing over long periods of up to 25 years. The PHC has carried out six housing projects in Gaza Strip [12].

United Nation for Relief and Work Agency (UNRWA) was established as a subsidiary body of the United Nations General Assembly on December /1949, and entered into force on May 1950. The Agency has played a key role for over 60 years in providing education, health, camp development, relief and social services to Palestinian refugees, community support, microfinance and emergency response at all times. It has also established emergency housing projects and rehabilitation projects for poor refugee families [13]. It has also established projects to rebuild destroyed houses and to absorb citizens whose homes were destroyed as a result of the Israeli wars and attacks on refugee homes in Gaza Strip during the intifada from 2000 to 2004, the 2006 war, 2009 war, 2012 war and then the war of 2014. UNRWA has carried out 7 housing projects in Gaza Strip [14].

There are international organizations that contribute to the housing sector in Gaza Strip, such as Qater Charity, Turkish Cooperation and Coordination Agency (TIKA), International Mercy Society, United Nations Development Programme (UNDP), Norwegian Refugee Council (NRC), and Others. 
These organizations target poor families who have no adequate shelter, affected by wars or disasters and disabled persons with special needs. This is accomplished through the construction of projects for the restoration or construction or delivery of ready housing units [9]. These institutions often rely on donations from countries or supporters of the Palestinian people, such as (Qatar, Turkey, Kuwait, Foreign donations, internal donations, etc.) [5].

Self Fund "Own Expense" Sector includes all the efforts made in the housing sector of the people "High-income and middle-income", especially those who create housing units for themselves and their families at their own expense. They represent a significant proportion of housing in Gaza Strip [8].

Private "main" Sector includes all private companies and investment banks involved in the field of housing through the establishment of investment housing projects and then sold or leased, or through bank loans for the construction of housing. This private sector is considered one of the most important and largest sectors contributing to the field of housing [8]. This residential sector is distinguished from other sectors. It is a profitable investment, and the specifications of the housing produced by this sector are often of a high standard in terms of geography, urbanization, building finishes, housing area, number of rooms, basic services and other features. Therefore, the target group in this housing sector is high-income and middle-income [15].

\section{Literature Review}

\subsection{Evaluation of Public Housing Projects}

Evaluation is identifying and assessing of public housing projects outcomes. They help evaluation users to maintain their focus on meeting the citizen needs of housing; assess and record their level of success in reaching and meeting the beneficiaries' targeted needs [16-18]; identify intended and unintended side effects; assess the funding policies, strategies and locations of public housing projects; assess criteria for selecting the target group to benefit from the public housing project; assess the achievement of social objectives, then make informed decisions to improve the effort. Evaluations should serve government officials of housing "MPWH", policy boards, counselors, engineers, social workers, and other service providers, and funding organizations, regulatory bodies, and society at large. Evaluators should present their audiences with evaluations that help develop suitable effective solutions to deal with housing crisis; help identify and assess alternative improvement options; help assure high quality and ongoing improvement of services; certify the effectiveness of services; expose deficient; and help clarify the factors that influenced the housing projects success or failure [19]. It is expected that the study will bridge some gaps in literature on evaluation of public housing projects; and extend our understanding of the key elements that could be manipulated to improve the role of government in alleviating the housing crisis and the performance of residential buildings in public housing schemes in Gaza Strip.

\subsection{Housing Policies and Strategies}

Housing policies and strategies are important aspects to be taken into account to assess the results achieved by the housing sector. Given the significant role it plays in guiding and determining the results that this sensitive sector must reach, we often hear "the success of a country's housing policy" or the phrase "failure of a country's housing policy" [20].

Makhoul and Mutiani defined in 2002 public policy as a set of laws and regulations that define and clarify the rights and obligations of the parties concerned, and the housing sector is one of the most important sectors in which countries interfere in their policies due to the private fragility of this sector and its impact on all sectors in any country and its prosperity and welfare [21]. Government intervention includes licenses, standards, project plans, and infrastructure, and land market, legal matters related to finance and its management, and any aspect affecting the housing sector.

The national housing strategies are a plan of action aimed at achieving certain long-term goals. It is the cornerstone of urban policy in any country. It is a set of activities that guide policies, planning and programming for investment, management and maintenance activities in the areas of housing [22]. These strategies should be developed with the full participation of the competent authorities and the relationship, and all that affects the urban planning and management process must be included and all within a supportive legal and regulatory framework. In addition, the national housing strategies are aimed at improving slums and preventing their emergence in general [22].

UN-Habitat clarified in 2013 that there are no approve and clear public housing policy and national housing strategy in Gaza Strip, but an attempt was made by the United Nations Human Settlements Program, a policy aimed at realizing the vision of "sustainable human settlements, with decent housing for all Palestinian families" through five main objectives [23] which includes enabling all citizens to have adequate, healthy and affordable housing, encourage the establishment of a new sustainable growth model for human settlements in Palestine that takes into account the limited land and natural resources of this country, increase access to housing finance for all Palestinians, supporting and developing the local reconstruction sector and introducing new patterns of construction, improving the institutional capacity of housing sector bodies [23].

Ismail presented in 2000 his study a number of proposals on the national housing policy. The most prominent of these were the creation of specialized financing institutions, the establishment of appropriate frameworks and mechanisms for lending housing projects, and the provision of incentives for the financial sector; Investments, and the classification of beneficiaries into categories according to the level of personal income. Then the role of the State is limited to 
assisting low-income groups and leaving the private sector to deal with middle and high income groups [24].

\subsection{Social Objectives of Housing Projects}

The primary purpose of houses is to provide occupants with conducive, safe, comfortable, healthy and secured indoor environment to carry out different kinds of activities ranging from work, study, leisure and family life to social interactions. In order to achieve this purpose, buildings are designed, planned, constructed and managed based on standards and specifications established by governments, professionals and experts who are supposed to have adequate knowledge of users' needs and expectations. Studies of Zeiler and Boxem in 2008 have however shown that sometimes these standards and specifications do not conform to the changing needs and expectations of users; and thus, users are not always satisfied with the performance of their buildings [25]. The consequences of this are manifested in building related illness and 'sick building syndrome'[26], increase in the desire for remodeling or modifications or abandonment of completed buildings [27] which may cause waste of energy and sometimes even damage to the building envelope components and the surrounding environment [28].

The evidence shows that public housing projects support multiple social objectives; this includes improvements to individual outcomes such as employability, crime, health and wellbeing, and community cohesion [29]. It is particularly important to assess the socio-economic impact of public housing projects in light of the large set of households where demand for public housing cannot currently be met [30].

\subsection{Criteria for Selecting the Target Group of Public Housing Projects}

Historically, local authority registers have not always been an effective way of measuring need for public housing as waiting lists reflect demand, which is not necessarily the same as the eligibility criteria for being housed in a public home. Recent reforms which have increased the power of local authorities to determine who is and isn't eligible for public housing mean that the most recent figures are less likely to include those that aren't eligible for housing (Ministry of Housing Communities \& Local Government [31]. Though the problem of some of those in need not being on registers is likely to remain. Therefore, local authority waiting list figures provide a useful indication of the scale of demand relative to new public housing supply, but may not be a completely accurate measure of need [32].

Housing strategies are mainly designed to provide suitable conditions for housing different limited income segments according to common and acceptable criteria, but the identification of these criteria is fraught with difficulties [10]. Schneider and Igram defined in 1993 social construction of target groups as "the cultural characterizations or popular images of the persons or groups whose behavior and well-being are affected by public policy."[33] These characterizations are not neutral but "normative and evaluative" and they portray specific societal groups "in positive or negative terms through symbolic language, metaphors, and stories" [33]. Furthermore, a social construction "refers to (1) the recognition of the shared characteristics that distinguish a target population as socially meaningful, and (2) the attribution of specific, valenceoriented values, symbols, and images to the characteristics. Social constructions are influenced by stereotypes "that have been created by politics, culture, socialization, history, the media, literature, religion, and the like" [33].

This study adopted the division of the target groups of public housing projects into four main categories according to the socio-economic aspect, note that all four categories are of limited income are as follows: extremely low income, low income, middle income and middle-high income. In general, it is preferable for public housing projects to include each project on only one socio-economic category, in order to maintain the same social, economic and cultural level of the population as well as to maintain housing standards designed and cost suitable for all the population [10].

The most prominent criteria that guide the government in selecting the appropriate target group [10] are the nature of the project, the funding type, the cost, the house area, quality standards, standards for surrounding external services, the need for housing and standards of integrity, transparency and equality.

\subsection{The Geographical Location of the Public Housing Projects}

Location is a crucial component of building practice, as how people and goods get to and from the site affects the environmental performance of the building and its occupants. Choosing a location that offers transportation options and a variety of nearby destinations: Protects air and water quality, Preserves open space, Provides safety, security, comfort and well-being and Saves money and resources [34].

\subsection{The Main Barriers Facing the Government in Alleviating the Pausing Crisis in Gaza Strip}

A number of factors constrain the ability of developers to increase the supply of housing [30]. These factors contributed to the creation of this great crisis and the apparent lack of housing in Gaza Strip, some of which are related to political circumstances, others to economic, social, planning and organizational conditions. The following are the most important barriers that contributed to the creation of this great housing gap and hinder the government's efforts to alleviate the housing crisis: High population density and high annual population growth [4], Limited area of Gaza Strip [35], Shortage of available housing units [4], Rapid urban growth in Gaza Strip [36], Absence of a comprehensive strategy and clear policy for housing in Gaza Strip [9], The land and sea blockade imposed by the Israeli occupation on Gaza Strip for more than 12 years. The weak financial and economic resources of the government in Gaza Strip [9, 37], The weakness of external funding and grants allocated to the 
housing sector in the Gaza Strip [9, 37], Donor constraints on identifying basic variables for housing projects [9], The weakness of the government's capabilities to develop sufficient and efficient technological construction sectors [9, 37], The three consecutive wars on the Gaza Strip during the period from 2008 to 2017, which was the cause of the great destruction of the homes of citizens [9].

\section{Research Methodology}

Literature review is presented about housing. The sources have mainly been refereed to academic research journals, dissertation/theses, books, conferences and websites. A questionnaire survey was used as a main tool to collect data to achieve the research objective. The questionnaire was tested to make sure that all questions were easily understood. Piloting process was conducted by distributing the prepared questionnaire to seven experts having experience in the same field of the research. The experts were selected precisely based on their technical and managerial capabilities and their extensive knowledge and experience in public housing to be sure of adding a value for the questionnaire. The experts were asked to review the questionnaire and verify the validity of the questionnaire topics and its relevance to the research objective and give their advice. Generally, they believed that the questionnaire is suitable to achieve the objectives of the study. Important comments, modifications, suggestions, advices and recommendations were collected and evaluated carefully. Some minor modifications, changes and additions were conducted to the questions and the final questionnaire was constructed.

From an interview with executives and decision makers, the main key authorities in housing sector and the targeted population are identified. Besides the MPWH, there are other organizations have sufficient knowledge of public housing. Therefore, the targeted population were (governmental organizations, semi-governmental organizations, international agencies and academic and research institutions) working and interested in the issue of housing in Gaza Strip in addition to their knowledge of housing policies and their direct or indirect participation in public housing projects. The decision makers, executives and specialists of these organizations answered the questionnaire according to their experience in public housing sector. Table 1 shows the targeted population, number of the distributed questionnaires and the response rate.

Table 1. Research sample and response rates.

\begin{tabular}{|c|c|c|c|c|c|}
\hline Organization Type & Organization Name & $\begin{array}{l}\text { Targeted } \\
\text { Population }\end{array}$ & $\begin{array}{l}\text { Distributed } \\
\text { Questionnaire } \\
\text { Numbers }\end{array}$ & Response & $\begin{array}{l}\text { Response } \\
\text { Rate (\%) }\end{array}$ \\
\hline Governmental & Ministry of Public Works and Housing (MPWH) & 25 & 25 & 25 & $100 \%$ \\
\hline Semi-Governmental & Palestinian Housing Council (PHC) & 10 & 10 & 9 & $90 \%$ \\
\hline \multirow{5}{*}{ International } & $\begin{array}{l}\text { United Nations for Reliefs and Works Agency } \\
\text { (UNRWA) }\end{array}$ & 10 & 10 & 9 & $90 \%$ \\
\hline & United Nations Development Program (UNDP) & 5 & 5 & 4 & $80 \%$ \\
\hline & Gaza Re-construction Committee - Qatar & 10 & 10 & 9 & $90 \%$ \\
\hline & Kuwait International Mercy Society in Gaza & 5 & 5 & 4 & $80 \%$ \\
\hline & $\begin{array}{l}\text { Presidency of the Turkish Agency for } \\
\text { Cooperation and Coordination (TIKA) }\end{array}$ & 5 & 5 & 4 & $80 \%$ \\
\hline $\begin{array}{l}\text { Academic and } \\
\text { research }\end{array}$ & $\begin{array}{l}\text { Islamic University in Gaza - Researchers and } \\
\text { Experts in Housing }\end{array}$ & 10 & 10 & 9 & $90 \%$ \\
\hline Summation & & 80 & 80 & 73 & $91 \%$ \\
\hline
\end{tabular}

The questionnaire included a set of questions to evaluate the administrative, supervisory and financial public housing policies and the national housing strategies currently applied in Gaza Strip, and assess their role in contributing to the alleviation of the housing crisis. These questions and factors were explored through the researcher's experience and review of the supervisor and experts, in addition to that, several previous studies were used to select the factors which includes: [5, 6, 8-10, 12, 14, 15, 20, 21, 23-39]

\section{Results and Discussion}

Knowing the respondents' educational level is important to ensure that the responses received were from appropriate sources. It general, the participants' educational qualification in housing field consisted of three levels: "Bachelor's degree", "Master's degree" and "PhD". As shown in Table 2, those qualified respondents with "Bachelor's degree" made up the highest proportion, at $69.86 \%$, while the proportion of other participants with "Master's degree" and "PhD" stood at $21.92 \%$ and $8.22 \%$ respectively. It seems that the people working in housing field in Gaza Strip with higher qualifications including master's degree and Ph.D are fewer in number than those with bachelor's degree. However, it can be inferred from the above results that, most of the respondents have certain levels of educational background to provide the most suitable data for this study. 
Table 2. Respondents' profile.

\begin{tabular}{|c|c|c|c|c|}
\hline No. & Information about respondents & Categories & Frequency & Percent \% \\
\hline \multirow{3}{*}{1} & \multirow{3}{*}{ Educational qualification } & Bachelors & 51 & 69.86 \\
\hline & & Master & 16 & 21.92 \\
\hline & & $\mathrm{PhD}$ & 6 & 8.22 \\
\hline \multirow{6}{*}{2} & \multirow{6}{*}{ Specialization } & Engineering (Civil, Architectural) & 35 & 47.95 \\
\hline & & Geography & 5 & 6.85 \\
\hline & & Sociology & 14 & 19.18 \\
\hline & & Management & 8 & 10.96 \\
\hline & & Law and political & 5 & 6.85 \\
\hline & & Other & 6 & 8.22 \\
\hline \multirow{4}{*}{3} & \multirow{4}{*}{ Workplace } & Governmental org. & 35 & 47.95 \\
\hline & & Semi-governmental org. & 8 & 10.96 \\
\hline & & International org. & 26 & 35.62 \\
\hline & & Academic / research org. & 4 & 5.48 \\
\hline \multirow{4}{*}{4} & \multirow{4}{*}{ Experience in housing field } & Less than 5 years & 8 & 10.96 \\
\hline & & (5 - Less than 10 years) & 19 & 26.03 \\
\hline & & (10 - Less than 15 years) & 29 & 39.72 \\
\hline & & 15 years and above & 17 & 23.29 \\
\hline
\end{tabular}

The participants had different specialization backgrounds ranging from engineering to law, political specialists and others. In fact, having perceptions from respondents with a variety of specializations is an advantage. Participants in the questionnaire were asked which specialization category they fell into. Table 2 illustrates that those in the "Engineering (Civil, Architectural)" category compared to the other categories were the highest, accounting for $47.95 \%$. The next was "Sociology" at $19.18 \%$, followed by "Management" at $10.96 \%$. The lowest belonged to "Law and political" and "Geography" categories representing just $6.85 \%$ for each category.

The participants in housing field in Gaza Strip were employed in public and private sectors, with some of them employed in both sectors at the same time. The participants from the "Governmental organizations" represented nearly half of the total participants $(47.95 \%)$, with the proportion for this is higher in comparison with the other sectors, while those who are engaged in "International organization" have the second proportion of $35.62 \%$. These ratios of respondents' workplace are very important in supporting these research objectives by providing several views from different organizations.

Most respondents were in the experience range of " 10 Less than 15 years" representing $39.72 \%$ of the respondents. On the other hand, the rest of the groups which are " 5 - Less than 10 " years of experience and the group which was having more than " 15 years and above" of experience representing $26.03 \%$ and $23.29 \%$, respectively. A small percentage of respondents reported less than five year of work experience with $10.96 \%$. On the base of these results, it can be shown than most respondents have experience of "5 years and above" in housing field with cumulative percent equals to $89.04 \%$. This profile confirms the considerable experience on which the responses to this survey were based. So that, this is reasonable to infer that major respondents for this study survey have a reasonable knowledge of the activities associated with housing field in Gaza Strip.

\subsection{Evaluation of the Current Government's Policies and Strategies of Housing in Gaza Strip}

The existence of a strategy and comprehensive Palestinian housing policies accompanied by compatible implementation policies has become a pressing need for addressing the serious housing crisis and the problem of populations in Palestinian territories. The statistical analysis is reported in Table 3. A ranking of the top 10 important variables was carried out to determine the relative application of the various policies and strategies. A one sample t-test was carried out to determine whether the population agreed that the contents of a specific policy are applied or otherwise.

Table 3. Evaluation of the government's current policies and strategies in the housing field in Gaza Strip.

\begin{tabular}{|c|c|c|c|c|c|c|c|}
\hline No. & Indicator & MS & RII & SD & t-value & P-value & Rank \\
\hline 1 & $\begin{array}{l}\text { Government policies for housing are mostly ideas and views that exist in } \\
\text { the minds of specialists and officials of the housing sector }\end{array}$ & 4.11 & 82.19 & 0.79 & 11.98 & 0.00 & 1 \\
\hline 2 & $\begin{array}{l}\text { Government housing policies and laws guarantee the settlement of } \\
\text { beneficiaries in the public housing and not sell, lease or use them for any } \\
\text { other purposes }\end{array}$ & 3.71 & 74.25 & 0.81 & 7.54 & 0.00 & 2 \\
\hline 3 & $\begin{array}{l}\text { Government policies establish appropriate mechanisms to overcome } \\
\text { housing projects constraints imposed by donor restrictions or conditions }\end{array}$ & 3.68 & 73.70 & 0.83 & 7.04 & 0.00 & 3 \\
\hline 4 & $\begin{array}{l}\text { The plan and its projects are commensurate with the available internal and } \\
\text { external capabilities }\end{array}$ & 2.86 & 57.26 & 0.80 & -1.45 & 0.15 & 4 \\
\hline 5 & $\begin{array}{l}\text { Housing policies encourage citizens to build their homes by simplifying } \\
\text { procedures for issuing building permits }\end{array}$ & 2.60 & 52.05 & 0.79 & -4.27 & 0.00 & 5 \\
\hline 6 & $\begin{array}{l}\text { Government housing policies strengthen mutual trust between external } \\
\text { donors and the government }\end{array}$ & 2.40 & 47.95 & 0.91 & -5.67 & 0.00 & 6 \\
\hline
\end{tabular}




\begin{tabular}{|c|c|c|c|c|c|c|c|}
\hline No. & Indicator & MS & RII & SD & t-value & P-value & Rank \\
\hline 7 & Government housing policies promote equitable access to housing. & 2.27 & 45.48 & 0.85 & -7.26 & 0.00 & 7 \\
\hline 8 & $\begin{array}{l}\text { The executive plan includes several housing projects to solve the housing } \\
\text { crisis }\end{array}$ & 2.22 & 44.38 & 0.75 & -8.90 & 0.00 & 8 \\
\hline 9 & $\begin{array}{l}\text { The government benefits from the experience of other countries in the area } \\
\text { of housing when formulating housing policies and strategic plans }\end{array}$ & 2.21 & 44.11 & 0.69 & -9.89 & 0.00 & 9 \\
\hline \multirow[t]{2}{*}{10} & $\begin{array}{l}\text { The government supports scientific research and encourages studies related } \\
\text { to the housing crisis }\end{array}$ & 2.16 & 43.29 & 0.58 & -12.36 & 0.00 & 10 \\
\hline & Total & 2.04 & 40.87 & 0.26 & -31.98 & 0.00 & \\
\hline
\end{tabular}

Table 3 shows that, the statement "Government policies for housing are mostly ideas and views that exist in the minds of specialists and officials of the housing sector" is ranked in the first order with $(\mathrm{MS}=4.11, \mathrm{RII}=82.19 \%$, $\mathrm{SD}=0.79$ ). Additionally, One-Sample T-test results reveal that the significance level value " $p$-value $=0.00$ " for this statement is less than " 0.05 " and the calculated (t-value= 11.98 ) is positive and larger than the critical t-value "1.99" which reveal that the mean score of the respondents' answers for this statement is significantly larger than the hypothesized mean " 3 ". In this line, it can be concluded that the respondents agreed that government policies for housing are mostly ideas and views that exist in the minds of specialists and officials of the housing sector. Abu Hayya in 2017 and MAS in 2015 coincide with our findings [9, 37]. Government housing policies have an important impact on the performance of the housing sector, and thus a significant effect on the economy as a whole. However, housing priorities are set by the professional staff that may have recourse to some sample surveys of consumer demand, but usually rely on their own beliefs of what people need or ought to have [40]. In fact, the PNA, represented by the MPWH, has made several attempts engaged with housing stakeholders in the formulation of housing policies and a national strategic plan for housing in the last few years. On the other hand, these policies and strategic plans are taken into account the political and economic conditions and thus being placed on an exceptional and temporary basis, and if they are placed without taking political and economic circumstances into consideration, they become unrealistic and impractical [9].

The respondents ranked the statement "Government housing policies and laws guarantee the settlement of beneficiaries in the public housing and not sell, lease or use them for any other purposes" in the second position with (MS=3.71, RII $=74.25 \%, \quad \mathrm{SD}=0.81)$. One-Sample T-test results show that the significance level value " $p$-value $=0.00$ " for this statement is less than " 0.05 " and the calculated ( $t$ value $=7.54)$ is positive and larger than the critical $t$ value"1.99" which imply that, the mean score of the respondents' answers for this statement is significantly larger than the hypothesized mean " 3 ". Hence, these results indicated that the respondents agreed that Palestinian government housing policies and laws guarantee the settlement of the beneficiaries in the public housing and not sell, lease or use them for any other purposes. In fact, the public housing projects and programs in the Gaza Strip are concerned with the provision of housing at nominal prices to low-income families that do not have adequate shelter. Therefore, the concerned authorities set conditions require that the beneficiary has no other shelter and thus; ensure the settlement of the beneficiary in the public house. In addition, the beneficiary is restricted through the contract by establishing contractual conditions that guarantee the settlement of the beneficiary in the public house and not to use it for other purposes such as rent or otherwise and not leave it empty.

The third rank from the proposed statements was occupied by the statement "Government policies establish appropriate mechanisms to overcome housing projects constraints imposed by donor restrictions or conditions" with $(\mathrm{MS}=3.68$, $\mathrm{RII}=73.70 \%, \mathrm{SD}=0.83)$. The significance level value " $p$ value $=0.00$ " for this statement is less than " 0.05 " and the calculated (t-value $=7.04)$ is positive and larger than the critical t-value "1.99" which point out that, the mean score is significantly larger than the hypothesized mean " 3 ". The respondents agreed that, Palestinian government policies establish appropriate mechanisms to overcome housing projects constraints imposed by donor restrictions or conditions. In fact, donors refrain from financing housing as an economic issue of which the government should not be party notwithstanding the need of Palestinian citizens for shelter and compensation for what the occupation destroys. So that, the Palestine Liberation Organization (PLO) appointed the Palestinian Housing Council (PHC) to be the sole body responsible for planning and implementing housing policy in the occupied territories with a particular focus on providing housing for middle and low-income Palestinians [40]. Mostly, the respondents understood the meaning of this question that the government is overcoming the obstacles with the donor to win the housing project. In general, it is concluded that the role of current public policies and national strategic plans was very weak in contributing to the alleviation of the housing crisis in Gaza Strip.

\subsection{Social Evaluation of Public Housing Projects Implemented in Gaza Strip from 1994 to 2017}

Table 4 indicated that the respondents put the social objective "Public housing projects provided decent and suitable housing for the population in terms of area (apartment, rooms, hall, kitchen, bathroom) and number of rooms" in the first rank from the proposed social objectives with $(\mathrm{MS}=4.44, \mathrm{RII}=88.77 \%, \mathrm{SD}=0.94)$. In addition, OneSample T-test results show that the significance level for this statement is less than " 0.05 " and the calculated (t-value= 13.04) is positive which indicate that, the mean score of the 
respondents' is significantly larger than the hypothesized mean " 3 ". Hence, the respondents agreed with high degree that public housing projects provided decent and suitable housing for the population in terms of area and number of rooms. This result was expected, because in fact all public housing projects have been planned, designed and supervised by competent government bodies that are keen to apply technical conditions and specifications of sufficient quality, often following internationally agreed rules and requirements. This results is consistent with the findings of the following research $[5,6,8,12]$.

Table 4. Evaluation of the public housing projects implemented in Gaza Strip from 1994 to 2017.

\begin{tabular}{|c|c|c|c|c|c|c|c|}
\hline No. & Social objective & MS & RII & SD & t-value & p-value & Rank \\
\hline 1 & $\begin{array}{l}\text { Public housing projects provided decent and suitable housing for the } \\
\text { population in terms of area (apartment, rooms, hall, kitchen, bathroom) and } \\
\text { number of rooms }\end{array}$ & 4.44 & 88.77 & 0.94 & 13.04 & 0.00 & 1 \\
\hline 2 & $\begin{array}{l}\text { Public housing projects provided housing suitable for all segments of the } \\
\text { population in terms of price, payment method and payment amount }\end{array}$ & 4.29 & 85.75 & 0.98 & 11.24 & 0.00 & 2 \\
\hline 3 & $\begin{array}{l}\text { Public housing projects provided adequate housing for the population in } \\
\text { terms of ventilation quality, lighting, thermal and sound insulation, and noise } \\
\text { protection }\end{array}$ & 3.96 & 79.18 & 0.96 & 8.50 & 0.00 & 3 \\
\hline 4 & $\begin{array}{l}\text { Public housing projects have achieved a high social and cultural standard } \\
\text { that is suitable for the population }\end{array}$ & 3.95 & 78.90 & 0.85 & 9.52 & 0.00 & 4 \\
\hline 5 & $\begin{array}{l}\text { Public housing projects have taken into account the customs and traditions } \\
\text { of society }\end{array}$ & 3.85 & 76.99 & 0.91 & 7.99 & 0.00 & 5 \\
\hline 6 & $\begin{array}{l}\text { Public housing projects have provided a high level of safety, tranquility and } \\
\text { protection for the population }\end{array}$ & 3.85 & 76.99 & 0.89 & 8.13 & 0.00 & 6 \\
\hline 7 & $\begin{array}{l}\text { Public housing projects provided basic services to the population (health, } \\
\text { education and infrastructure) }\end{array}$ & 3.78 & 75.62 & 0.93 & 7.16 & 0.00 & 7 \\
\hline 8 & $\begin{array}{l}\text { Public housing projects have provided health facilities that have contributed } \\
\text { to reducing the rate of injuries and illnesses caused by poor housing in } \\
\text { Palestinian society }\end{array}$ & 3.64 & 72.88 & 0.79 & 6.98 & 0.00 & 8 \\
\hline 9 & $\begin{array}{l}\text { Public housing projects have achieved an appropriate level of comfort and } \\
\text { well-being for the population through the provision of luxury services such } \\
\text { as garages, playgrounds, parks, green spaces, markets, etc }\end{array}$ & 3.14 & 62.74 & 0.73 & 1.60 & 0.11 & 9 \\
\hline 10 & $\begin{array}{l}\text { Public housing projects have reduced the unemployment rate in Palestinian } \\
\text { society }\end{array}$ & 3.03 & 60.55 & 0.74 & 0.31 & 0.75 & 10 \\
\hline 11 & $\begin{array}{l}\text { Public housing projects have positively impacted the increase in income } \\
\text { through the operation of contractors, consultants, suppliers, vendors, etc }\end{array}$ & 2.90 & 58.08 & 0.67 & -1.22 & 0.23 & 11 \\
\hline \multirow[t]{2}{*}{12} & $\begin{array}{l}\text { Public housing projects have contributed to the reduction of the crime rate in } \\
\text { Palestinian society }\end{array}$ & 2.89 & 57.85 & 0.71 & -1.19 & 0.25 & 12 \\
\hline & Total & 3.64 & 72.88 & 0.59 & 9.29 & 0.00 & \\
\hline
\end{tabular}

The second position "Public housing projects provided housing suitable for all segments of the population in terms of price, payment method and payment amount" with (MS = 3.96, RII $=85.75 \%, \mathrm{SD}=0.98)$. One-Sample T-test results with $(\mathrm{p}$-value $=0.00, \mathrm{t}$-value $=11.24)$, indicate significantly different than the hypothesized mean "3". Accordingly, the mentioned results for this statement revealed that, the study respondents agreed that, public housing projects provided housing suitable for all segments of the population in terms of price, payment method and payment amount. This result is in line with the reality that most of the public housing projects in Gaza Strip are grants from donors and the payment system is very convenient where the instalment amounts to $\$ 100$ per month and for up to 20 years, taking into account the monthly income and the socio-economic status of the family. Sometimes the apartments are given free of charge to poor beneficiaries whose income is less than a certain peak or those with no income $[5,10,12]$.

"Public housing projects provided adequate housing for the population in terms of ventilation quality, lighting, thermal and sound insulation, and noise protection" is the third rank social objective with $(\mathrm{MS}=4.44, \mathrm{RII}=79.18 \%$, $\mathrm{SD}=0.96)$. The inferential statistics with $(\mathrm{p}$-value $=0.00, \mathrm{t}-$ value $=8.50$ ) according the One-Sample T-test results indicated that the mean score for this statement is significantly different from the hypothesized value "3". So that, the respondents agreed that, public housing projects provided adequate housing for the population in terms of ventilation quality, lighting, thermal and sound insulation, and noise protection. In fact, public housing projects have been planned, designed and supervised by government agencies that are keen to apply technical conditions and specifications of sufficient quality, often following internationally agreed rules and requirements. This result is consistent with the results of the following studies $[6,8,12]$.

In general, Table 4 shows that, the respondents agreed about the social objectives of the public housing projects implemented in Gaza Strip from 1994 to 2017 with overall statistical results for this part with $(\mathrm{MS}=3.64, \mathrm{RII}=72.88 \%)$. The low overall standard deviation $(\mathrm{SD}=0.59)$ for this part is less than " 1 " which implies that there is a moderate level of agreement among the respondents in rating the social objectives involved in this part. The inferential statistics of the One-Sample t-test reveals that there is a sufficient evidence to imply that the respondents agreed about the social objectives of the public housing projects implemented 
in Gaza Strip. These results are positive and desirable, urging that they encourage beneficiaries to settle in public housing and thus contribute effectively to alleviating the housing crisis in the Gaza Strip.

\subsection{Geographical Location Evaluation for the Public Housing Projects}

As observed in the Table 5, this part has overall statistical results with $(\mathrm{MS}=3.53, \mathrm{RII}=70.66 \%, \mathrm{SD}=0.55)$. These results imply that some criteria from the proposed criteria are considered by the Palestinian government when selecting the geographical location for the public housing projects. Furthermore, the fact that the overall and all statement standard deviations are less than " 1 " indicates that there is a clear consistency and little variability in the data obtained from the respondents' answers for the statement involved in this part. Additionally, based on the t-test results, six items listed in the questionnaire with a significance level less than " 0.05 ", which indicates that, there is sufficient evidence that there is a clear agreement between the respondents about the consideration of the criteria involved in each one of these statements in selecting the geographical location for the public housing projects. However, four statements have significance levels larger than " 0.05 ", which mean that there is insufficient evidence to conclude that the criteria involved in these statements are considered in selecting the geographical location for the public housing projects. In general, it can be concluded that there is sufficient evidence that Palestinian government considers some criteria "insufficient and non-exhaustive criteria" when determining the geographical location for the public housing projects.

Table 5. Evaluation of the geographical location for the public housing projects implemented from 1994 to 2017 in Gaza Strip.

\begin{tabular}{|c|c|c|c|c|c|c|c|}
\hline No. & Geographical criterion & MS & RII & SD & t-value & P-value & Rank \\
\hline 1 & $\begin{array}{l}\text { Geographical location of public housing projects is often chosen to be close } \\
\text { to the municipalities and under its influence in order to benefit from its } \\
\text { services }\end{array}$ & 3.92 & 78.36 & 0.78 & 10.09 & 0.00 & 1 \\
\hline 2 & $\begin{array}{l}\text { The possibility } \mathrm{f} \text { future expansion is taken into account when choosing the } \\
\text { geographical location of the public housing projects. }\end{array}$ & 3.90 & 78.08 & 0.87 & 8.89 & 0.00 & 2 \\
\hline 3 & $\begin{array}{l}\text { Technical and engineering considerations and urban planning considerations } \\
\text { are taken into consideration when determining the geographical location of } \\
\text { public housing projects }\end{array}$ & 3.87 & 77.40 & 0.83 & 8.84 & 0.00 & 3 \\
\hline 4 & $\begin{array}{l}\text { Ease of movement and traffic of all mechanisms and equipment required for } \\
\text { construction are all taken into consideration when choosing the geographical } \\
\text { location of public housing projects }\end{array}$ & 3.85 & 77.00 & 0.81 & 8.76 & 0.00 & 4 \\
\hline 5 & $\begin{array}{l}\text { The selection of the public housing projects geographical location is related } \\
\text { to slums and encroachments on government land }\end{array}$ & 3.81 & 76.16 & 0.84 & 8.18 & 0.00 & 5 \\
\hline 6 & $\begin{array}{l}\text { Public housing projects are distributed in all governorates of Gaza Strip in a } \\
\text { professional manner and according to need/demand/disability in each } \\
\text { governorate }\end{array}$ & 3.77 & 75.34 & 0.87 & 7.78 & 0.00 & 6 \\
\hline 8 & $\begin{array}{l}\text { Geographical location of public housing projects is often chosen to be close } \\
\text { to public facilities, health centers and educational centers }\end{array}$ & 3.01 & 60.27 & 0.57 & 0.21 & 0.84 & 8 \\
\hline 9 & $\begin{array}{l}\text { The surrounding environmental and health conditions are taken into } \\
\text { consideration when determining the geographical location of public housing } \\
\text { projects }\end{array}$ & 3.01 & 60.27 & 0.63 & 0.18 & 0.85 & 9 \\
\hline \multirow[t]{2}{*}{10} & $\begin{array}{l}\text { Costs to prepare the site for construction is taken into consideration when } \\
\text { determining the geographical location of public housing projects }\end{array}$ & 2.99 & 59.73 & 0.59 & -0.20 & 0.84 & 10 \\
\hline & Total & 3.53 & 70.66 & 0.55 & 8.22 & 0.00 & \\
\hline
\end{tabular}

The first rank is occupied by the statement "Geographical location of public housing projects is often chosen to be close to the municipalities and under its influence in order to benefit from its services" with (MS=3.92, RII $=78.36 \%$, $\mathrm{SD}=0.78$ ). The mean score for this statement is larger and significantly different from the hypothesized mean "3" because the (p-value $=0.00)$. Therefore, the respondents clearly agreed that, government selected the location of its public housing projects to be within the municipality's boundaries and close to its services. These results are consistent with the studies of Zoarab in 2015 and Zaqout in 2011 [8,14]. In fact, this factor is one of the most important factors that encourage beneficiaries to settle in the public housing. The proximity of public housing to municipal services makes it easier for the beneficiaries to receive all the necessary basic services in their daily lives [14].

"The possibility of future expansion is taken into account when choosing the geographical location of the public housing projects" is ranked in the second position with $(\mathrm{MS}=3.90$, $\mathrm{RII}=78.08 \%, \mathrm{SD}=0.87$ ). One-Sample T-test results show that the respondents agreed that, the possibility of future expansion is taken into account when choosing the geographical location of the public housing projects. These results are positive, indicating that the geographical location of public housing projects is subject to the criteria of housing sustainability in order to solve the housing problem in Gaza Strip in the future. These results are consistent with the study of [8].

Table 5 also demonstrates that, the statement "The 
surrounding environmental and health conditions are taken into consideration when determining the geographical location of public housing projects" is located in the ninth position which is the penultimate position from the proposed statements in this part with $(\mathrm{MS}=3.01, \mathrm{RII}=60.27 \%$, $\mathrm{SD}=0.63)$. The results of the One-sample t-test indicate that, the mean score of the respondents' answers for this statement is not significantly different from the hypothesized mean " 3 " because its significance level value $(\mathrm{P}$-value $=0.85)$ is larger than " 0.05 " and the calculated (t-value $=0.18)$ is smaller than the critical t-value "1.99". The positive sign of the calculated tvalue implies that, the mean score of the respondents' answers for this statement is larger than the hypothesized value " 3 ". So that, it can be stated that, there is insufficient evidence to conclude that, the respondents agreed or disagreed about the contents of this statement. Accordingly, the aforementioned results reflect indication that, the study respondents didn't provide any clear viewpoints about the consideration of the surrounding environmental and health conditions when choosing the geographical location of public housing projects. It seems that the difference in public housing projects from each other in this regard, since some of them took these considerations into account while others did not.

The statement that is ranked in the last position from the studied statement is "Costs to prepare the site for construction is taken into consideration when determining the geographical location of public housing projects" with (MS=2.99, RII=59.73.277\%, SD=0.63). The One-Sample ttest reveals that, the respondents did not agree or disagree about the content of the statement. Although the mean score is less than the hypothesized value " 3 ", there is insufficient evidence to state that, the respondents disagreed that, costs to prepare the site for construction is taken into consideration when determining the geographical location of public housing projects. It is clear that this criterion is considered unimportant or that its importance is very small in influencing the solution of the housing crisis. Therefore, its ranking is the latter, and the respondents did not give a clear answer.

\subsection{Evaluating the Method of Selecting Target Group for Public Housing}

Table 6 summarizes the statistical results for the top 10 important statement involved in section according to the respondents' answers. The overall results for this part with $(\mathrm{MS}=3.72, \mathrm{RII}=74.31 \%, \mathrm{SD}=0.36)$ indicate that, there are several standards (criteria) that are considered by the Palestinian government when selection the target group for the public housing project. In addition, the all statements and the overall standard deviations are less than " 1 ", which mean that, the responses provided a less spread out or dispersed responses and it provided homogeneous data which argued that, there is a clear agreement between the ratings given by the respondents for these statements. Additionally, The OneSample T-test results show that the respondents agree that the beneficiaries for the public housing projects are selected by the Palestinian government on the base previously proposed criteria. It can be argued that, there is sufficient evidence that Palestinian government considers some standards when selecting the target group for the public housing projects, while there are other criteria that have not been taken into account by the Palestinian government. The Palestinian government must review, amend and update criteria for selecting the target group and develop appropriate mechanisms to ensure that all criteria are applied.

Table 6. Evaluating the method of selecting the target group for public housing projects implemented from 1994 to 2017 in Gaza Strip.

\begin{tabular}{|c|c|c|c|c|c|c|c|}
\hline No. & Standard & MS & RII & SD & t-value & P-value & Rank \\
\hline 1 & $\begin{array}{l}\text { The government gives priority to public housing projects targeting poor } \\
\text { families. }\end{array}$ & 4.34 & 86.85 & 0.85 & 13.44 & 0.00 & 1 \\
\hline 2 & $\begin{array}{l}\text { The government gives priority to public housing projects targeting } \\
\text { middle-income citizens }\end{array}$ & 4.05 & 81.10 & 0.62 & 14.51 & 0.00 & 2 \\
\hline 3 & $\begin{array}{l}\text { The government announces the registration of the public housing } \\
\text { project using various means and media to ensure that the advertisement } \\
\text { reaches all members of the target group }\end{array}$ & 4.03 & 80.55 & 0.60 & 14.62 & 0.00 & 3 \\
\hline 4 & $\begin{array}{l}\text { The government implements the principles of integrity, transparency, } \\
\text { equality and social justice in its selection of beneficiaries of public } \\
\text { housing projects }\end{array}$ & 4.00 & 80.00 & 0.62 & 13.70 & 0.00 & 4 \\
\hline 5 & $\begin{array}{l}\text { The government divides limited income citizens into several categories } \\
\text { depending on their economic and social situation }\end{array}$ & 3.99 & 79.73 & 0.61 & 13.76 & 0.00 & 5 \\
\hline 6 & $\begin{array}{l}\text { The government establishes a reasonable and sufficient period of time } \\
\text { for registration in public housing projects }\end{array}$ & 3.99 & 79.73 & 0.61 & 13.76 & 0.00 & 6 \\
\hline 7 & $\begin{array}{l}\text { The government publishes public lottery results in magazines, } \\
\text { newspapers and official websites }\end{array}$ & 3.97 & 79.45 & 0.64 & 12.89 & 0.00 & 7 \\
\hline 8 & $\begin{array}{l}\text { The government takes into account the cost criterion when selecting the } \\
\text { target group }\end{array}$ & 3.96 & 79.18 & 0.59 & 13.94 & 0.00 & 8 \\
\hline 9 & $\begin{array}{l}\text { The government relies on the "Scores system" in selecting the } \\
\text { beneficiaries of public housing projects targeting the poor }\end{array}$ & 3.96 & 79.18 & 0.63 & 12.94 & 0.00 & 9 \\
\hline \multirow[t]{2}{*}{10} & $\begin{array}{l}\text { The government adopts a rigorous research system to ensure that the } \\
\text { conditions and criteria are met in candidates to benefit from public } \\
\text { housing projects }\end{array}$ & 3.96 & 79.18 & 0.61 & 13.41 & 0.00 & 10 \\
\hline & Total & 3.72 & 74.31 & 0.36 & 16.87 & 0.00 & \\
\hline
\end{tabular}


It can be shown from Table 6 that the respondents ranked the statement "The Government gives priority to public housing projects targeting poor families" in the first rank from the proposed standards followed in the selecting the beneficiaries of the public housing projects with $(\mathrm{MS}=4.34$, $\mathrm{RII}=86.85 \%, \mathrm{SD}=0.85$ ). One-Sample T-test results show that there is a considerable agreement that the government gives priority to public housing projects targeting poor families. This result is realistic and conforms to the definition and basic purpose of public housing projects.

In the second rank, the study respondents put the standard "The government gives priority to public housing projects targeting middle-income citizens" with (MS=4.05, $\mathrm{RII}=81.10 \%, \mathrm{SD}=0.62$ ). The One-Sample t-test reveals that on overall, the mean score of this part is significantly larger than the hypothesized mean " 3 ". The middle-income families are considered by high degree by the Palestinian government when selecting the beneficiaries of the public housing projects. This is also a realistic result; the public housing project targets the limited-income group, which includes the middle-income. This is particularly important after the lowincome group is the middle-income.

The next important statement "The government announces the registration of the public housing project using various means and media to ensure that the advertisement reaches all members of the target group" with $(\mathrm{MS}=4.03$, $\mathrm{RII}=80.55 \%, \mathrm{SD}=0.60)$. The significance level value " $p$ value $=0.00$ " and the calculated $(t$-value $=14.62)$ is positive which point out that, the mean score of the respondents' answers for this statement is significantly larger than the hypothesized mean "3". The respondents agreed that, the government announces the registration of the public housing project using various means and media to ensure that the advertisement reaches all members of the target group. These results are positive and indicate that all citizens have access to public housing in an impartial and fair manner without any discrimination among members of society.

\subsection{Barriers that Hinder the Government's Efforts in Reducing the Housing Crisis in Gaza Strip}

Table 7 shows all barriers under consideration are significant since all of them with a significance level p-value less than " 0.05 " at $95 \%$ confidence interval. The mean score for each item is significantly different from the hypothesized mean " 3 ". Additionally, the first 8 barriers have a calculated t-values with positive sign and larger than the critical t-value "1.99", which mean that the respondents agreed that these 8 barriers have considerable effect in hindering the Palestinian governmental efforts in solving the housing problem in Gaza Strip. Moreover, all barriers in Table 7 have standard deviations less than " 1 " which reveals that there is a little variability in the data obtained from the respondents' responses for these barriers. Therefore, this result suggests considerable agreement among respondents in the way by which these barriers were interpreted. In furtherance, discussion on the one sample t-test below is expected to give some possible reasons.

Table 7. Barriers that hinder the government's efforts in reducing the housing crisis in Gaza Strip.

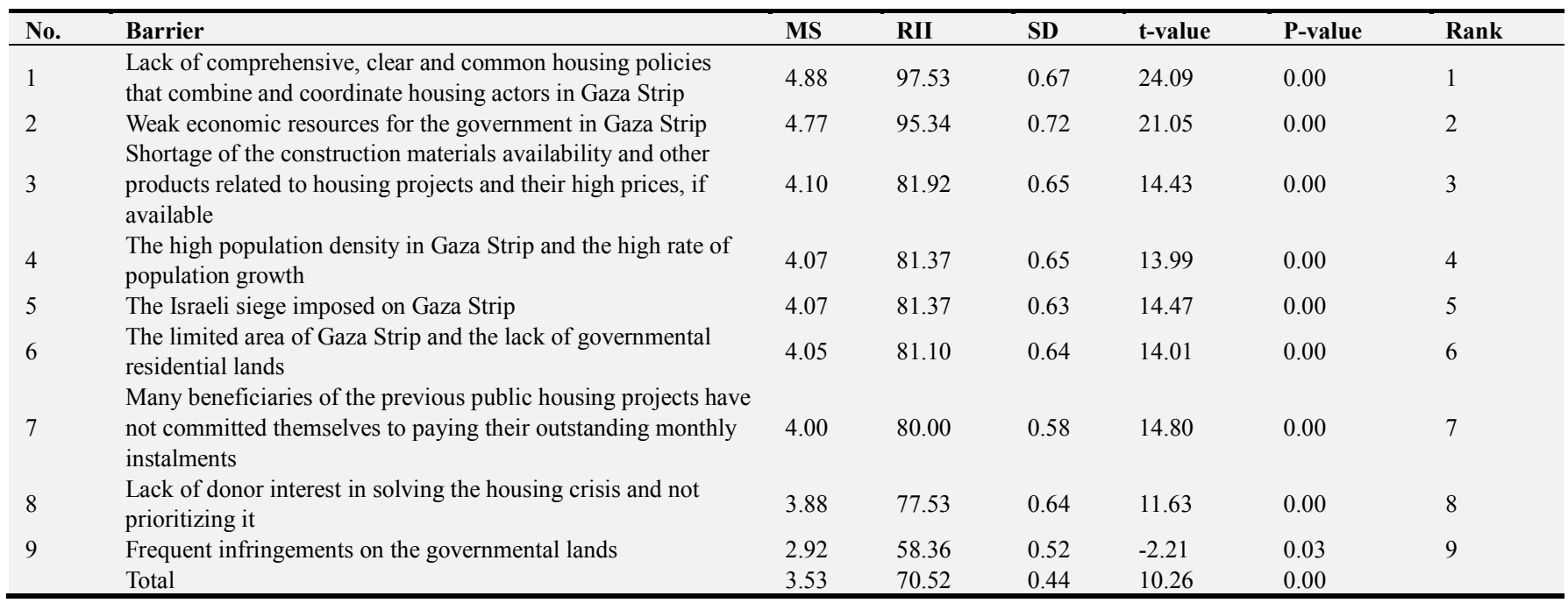

The barrier named "Lack of comprehensive, clear and common housing policies that combine and coordinate housing actors in Gaza Strip" with (M=4.88, RII=97.53\%, $\mathrm{SD}=0.67$ ) is ranked as the first barrier that impeding the Palestinian government efforts in solving the housing crisis in Gaza Strip. This result suggests that there is a sufficient evidence to report that, lack of comprehensive, clear and common housing policies that combine and coordinate housing actors in Gaza Strip is a key factor that adversely affects the governmental efforts in solving the housing problem. This result conforms to Abu Hayya [9].

The second rank barrier is "Weak economic resources for the government in Gaza Strip" with $(\mathrm{M}=4.77$, RII=95.34\%, $\mathrm{SD}=0.72$ ). The unavailability of the financial resources for the Palestinian government is considered as one of the main reasons causing hindering the Palestinian government efforts 
in solving the housing crisis in Gaza Strip. The One-Sample T-test reveals that there is sufficient evidence to say that the government's efforts to resolve the housing crisis in Gaza Strip are constrained by the weak economic resources of the government in Gaza Strip. There are many other housing studies that agreed with these findings and showed that the weak financial and economic resources of the government in Gaza Strip, is one of the most important obstacles to resolving the housing crisis in Gaza Strip [6, 9, 38].

\section{Conclusion}

The most important conclusion of this research is that "the public housing projects and public housing policies role has a very low rate in alleviating the housing crisis in Gaza Strip during, while the main contribution to the alleviation of the housing crisis is due to the private sector and selfconstruction of housing.

It is concluded that the most important and first step in the process of solving the housing crisis is the development of realistic and appropriate public housing policies and strategic plans that encouraging the private sector to invest in housing field. The study findings indicated that the Government policies for housing are mostly ideas and views that exist in the minds of specialists and officials of the housing sector. They are often not written in regulations and are not constantly updated and developed. However, there have been several attempts made during the past few years by the government agencies involved in partnership with other parties concerned to develop public housing policies and housing strategic plans, but these attempts described incomplete because it was facing some obstacles, the most important of them are the weakness of the national economy and unrealistic, there is also confused concepts between strategic plans and policies. Also the sustainability situation of public housing projects is very weak.

In general, there is satisfaction about the achievement of social objectives from the public housing projects implemented in Gaza Strip. There is sufficient evidence that the Palestinian government considers most of the main criteria when determining the geographical location of public housing projects.

There are several standards (criteria) that are considered by the Palestinian government when selection the target group for the public housing project, while there are other criteria that have not been taken into account by the Palestinian government. The Palestinian government must review, amend and update criteria for selecting the target group and develop appropriate mechanisms to ensure that all criteria are applied.

There are several barriers and constraints that hinder the role of the government in solving the housing crisis in Gaza Strip. The main obstacles are Lack of comprehensive, clear and common housing policies that combine and coordinate housing actors in Gaza Strip, Weak economic resources for the government in Gaza Strip, The political division between West Bank and Gaza Strip, Shortage of the construction materials availability and other products related to housing projects and their high prices, The high population density in Gaza Strip and the high rate of population growth, The limited area of Gaza Strip and the lack of governmental residential lands.

\section{Confect of Interest}

On behalf of all authors, the corresponding author states that there is no conflict of interest.

\section{References}

[1] United Nations Country Team in the Occupied Palestinian Territory. (2017). Gaza ten years later. Gaza Strip, Palestine: United Nations Country Team in the occupied Palestinian territory.

[2] Palestinian Central Bureau of Statistics (PCBS).(2017a). Palestine in Figures 2016. Ramallah, Palestine: Palestinian central bureau of statistical.

[3] Palestinian Central Bureau of Statistics (PCBS). (2014). Palestine in figures 2013. Ramallah, Palestine: Palestinian central bureau of statistical.

[4] Palestinian Central Bureau of Statistics (PCBS). (2017b). The Demographic Survey in the West Bank and Gaza Strip: Preliminary Report. Ramallah, Palestine: Palestinian central bureau of statistical.

[5] Ministry of Public Works and Housing (MPWH). (2017). Housing situation in Gaza Strip. Gaza Strip, Palestine: Ministry of Public Works and Housing.

[6] Al Agha, H. (2015). Estimating the Aggregate Demand Function for Housing in Palestine Case Study - Gaza Strip (1997 - 2013). "Master Thesis". Islamic University- Gaza, Palestine.

[7] Abu Hantash, I. (2009). Housing and Real Estate Loans in Palestine. Ramallah: Institute for Economic Policy Research (MAS).

[8] Zoarab, N. (2015). Residential Neighborhood between Theory and Practice and its Role in Housing Projects Planning in Gaza Strip "Master Thesis". Islamic University- Gaza, Palestine.

[9] Abu Hayya, M. (2017). Housing financing policies in Gaza strip and its influence on housing projects (Unpublished Master Thesis). Faculty of architecture, Islamic University, Gaza, Palestine.

[10] Yousef, M. (2002). Design standards for low-income housing. Master Thesis. An- Najah National University, Nablus, Palestine.

[11] Essawi, O. (2008). Proposed solutions for low-cost housing projects in the Gaza Strip. Islamic University Journal of Natural and Engineering Sciences, 34 (1), pp. 26-27.

[12] Palestinian Housing Council (PHC). (2017). Highlights on housing projects in the West Bank and Gaza Strip.. Ramallah, Palestine: Palestinian Housing Council.

[13] UNRWA. (2013). Gaza in 2020- UNRWA's response to information. Gaza Regional Office, Palestine: UNRWA. 
[14] Zaqout, A. (2011). Public Housing Projects in Gaza Governorates and their Suitability to Social, Environmental and Economic Reality. Master Thesis. Islamic UniversityGaza, Palestine.

[15] Naseer, A. (2004). Housing Policies between Reality and Future Aspirations. Paper presented at $2^{\text {nd }}$ International Conference on A Reality and an Ambition Housing, Amman.

[16] Parker, C., \& Mathews, B. P. (2001). Customer satisfaction: contrasting academic and consumers' interpretations. Marketing Intelligence \& Planning, 19 (1), 38-44.

[17] Ueltschy, L. C., Laroche, M., Eggert, A., \& Bindl, U. (2007). Service quality and satisfaction: an international comparison of professional services perceptions. Journal of Services Marketing, 21 (6), 410-423.

[18] Hanif, M., Hafeez, S., \& Riaz, A. (2010). Factors affecting customer satisfaction. International research journal of finance and economics, 60 (1), 44-52.

[19] Stufflebeam, D. L. (2007). CIPP evaluation model checklist. Retrieved January, 8, 2012.

[20] Ait, A. (2001). Financing the construction of housing in Algeria. Master Thesis. National Administration University, Algiers.

[21] Makhoul, B. and Mutiani (2002). The Role of the Construction and Housing Sector in Palestinian Economic Development. Ramallah: Institute for Economic Policy Research (MAS).

[22] Governing Council of the United Nations Human Settlements Program. (2013). Framework document for the Global Housing Strategy: twenty-fourth session. Nairobi: Governing Council of the United Nations.

[23] UN-HABITAT-United Nations Human Settlements Program. (2013). Draft National Housing Policy in Palestine. Ramallah, Palestine: UN-HABITAT-United Nations Human Settlements Program.

[24] Ismail, G. (2000). Towards a National Housing Policy in Palestine. An-Najah National University Journal, 10 (2), pp. 9-19.

[25] Zeiler, W., \& Boxem, G. (2008). Sustainable schools better than traditional schools?

[26] Kian, P. S., Feriadi, H., Sulistio, W., \& Seng, K. C. (2001). A case study on total building performance evaluation of an intelligent office building in Singapore. Civil Engineering Dimension, 3 (1), pp-9.

[27] Kim, S. S., Yang, I. H., Yeo, M. S., \& Kim, K. W. (2005). Development of a housing performance evaluation model for multi-family residential buildings in Korea. Building and environment, 40 (8), 1103-1116.
[28] Mitterer, C., Künzel, H. M., Herkel, S., \& Holm, A. (2012). Optimizing energy efficiency and occupant comfort with climate specific design of the building. Frontiers of Architectural Research, 1 (3), 229-235.

[29] Frontier Economics Limited in Europe. (2014). Assessing the social and economic impact of affordable housing investment. $A$ report prepared for $G 15$ and the national housing federation. London: Frontier Economics Limited in Europe.

[30] L\&Q and Pricewaterhouse Coopers. (2012). The Numbers Game: Increasing housing supply and funding in hard times. Brazil: L\&Q and Pricewaterhouse Coopers.

[31] Ministry of Housing Communities \& Local Government (MHCLG). (2012). Allocation of accommodation: guidance for local housing authorities. England: Ministry of Housing Communities \& Local Government.

[32] London Municipality. (2014). Mayor of London Office: Homes for London and The London Housing Strategy. London: The International Federation of Housing and Planning.

[33] Schneider, A., \& Ingram, H. (1993). Social construction of target populations: Implications for politics and policy. American political science review, 87 (2), 334-347.

[34] Tribal Green Building Toolkit. (2015): Provides information on how tribes and other communities can prioritize and implement green building codes, policies, and practices. London: Tribal Green Building Toolkit.

[35] Ministry of Local Government (MOLG). (2017). Municipalities of the Gaza Strip. Gaza Strip, Palestine: Ministry of Local Government.

[36] Saleha, R. (2011). demographic and urban indicators and their impact on the housing problem in the Gaza Strip. Ministry of Public Works and Housing Journal, 5 (1), pp. 10-11.

[37] Palestinian Economic Policy Research Institute (MAS). (2015). Jerusalem Regional Office. Palestine: Palestinian Economic Policy Research Institute.

[38] Mixed-Use Trip Generation Model. (2011): Spreadsheet tool that helps users estimate trips generated by a new mixed-use development. London: Mixed-Use Trip Generation.

[39] Cornwall; A. and Karen, B. (2005). Beyond buzzwords: "Poverty reduction", "participation" and "empowerment" in development policy. Geneva: United Nations Research Institute for Social Development.

[40] Barakat, S., Elkahlout, G., \& Jacoby, T. (2004). The reconstruction of housing in Palestine 1993-2000: a case study from the Gaza strip. Housing Studies, 19 (2), 175-192. 